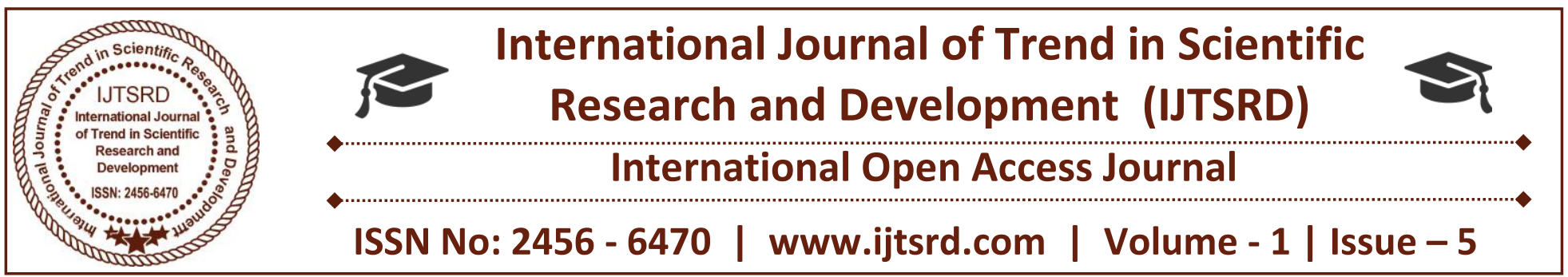

\title{
Investment Behavior among Generational Group
}

\author{
Angelin S. Kiruba \\ Research Scholar, School of Management Studies, \\ Vels University, Chennai, India
}

\author{
Dr. S Vasantha \\ Professor, School of Management Studies, \\ Vels University, Chennai, India
}

\begin{abstract}
Objective: Share Market investment is a lively platform to invest in the various industries. The objective of the study is to identify investment behavior of the different age groups and to find out the difference in perception of Investors in the decision of investing on the basis of Gender. This study aims to gain knowledge about key factors that influence investment behavior and ways these factors impact investment risk tolerance and decision making process among men and women and among different age groups. The individuals may be equal in all aspects, may even be living next door, but their financial planning needs are very different. It is by using different age groups along with Gender that synergism between investors can be generated. In this context, demographics alone no longer suffice as the

researchers have identified various factors influencing the behavior of an individual investors.

Findings: The paper identifies the importance given to the age factors influence in the investment sector and how it is plays the major role in the research papers on the investment behavior of the share market.

Novelty/Application: Although various papers have studied the investment behavior among the generational group not many have been able to analyze the antecedents of generational group in depth and study the impact of each on investment decision making of the investor. The paper has attempted to study these in detail.
\end{abstract} basis of segmentation of individual investors. Hence keeping this in mind, the present study is an attempt to find out Factors which affects individual investment decision and Differences in the perception of Investors in the decision of investing on basis of Age and on the basis of Gender. The study concludes that investor's age and gender predominantly decides the risk taking capacity of investors.

Methodology: The study is based on secondary data sources. For the present study, a thorough review of existing empirical literature has been collected from various online databases \& search engines such as SSRN\& Google scholar were reviewed and various books on Investor behavior were reviewed from various existing literature, Academicians\&

Keywords: Investment Behavior, Investor, Influence of generational gap

\section{INTRODUCTION}

Many individuals find investments to be fascinating because they can participate in the decision making process and see the results of their choices. Not all investments will be profitable, as investor wills not always make the correct investment decisions over the period of years; However, you should earn a positive return on a diversified portfolio. Investing is not a game but serious subject that can have a major impact on investor's future wellbeing. Virtually everyone makes investments. Even if the individual does not select specific assets such as stock, investments are still made through participation in pension plan, and employee saving program or through purchase of 
life insurance or a home or by some other mode of investment like investing in Real Estate (Property) or in Banks or in saving schemes of post offices. Each of this investment has common characteristics such as potential return and the risk you must bear. The future is uncertain, and you must determine how much risk you are willing to bear since higher return is associated with accepting more risk. (Lopes, 1987)

The individual should start by specifying investment goals. Once these goals are established, the individual should be aware of the mechanics of investing and the environment in which investment decisions are made. These include the process by which securities are issued and subsequently bought and sold, the regulations and tax laws that have been enacted by various levels of government, and the sources of information concerning investment that are available to the individual.

Today the field of investment is even more dynamic than it was only a decade ago. World event rapidly events that alter the values of specific assets the individual has so many assets to choose from, and the amount of information available to the investors is staggering and continually growing. The key to a successful financial plan is to keep apart a larger amount of savings and invest it intelligently, by using a longer period of time. The turnover rate in investments should exceed the inflation rate and cover taxes as well as allow you to earn an amount that compensates the risks taken. Savings accounts, money at low interest rates and market accounts do not contribute significantly to future rate accumulation. While the highest rate come from stocks, bonds and other types of investments in assets such as real estate. Nevertheless, these investments are not totally safe from risks, so one should try to understand what kind of risks are related to them before taking action. The lack of understanding as how stocks work makes the myopic point of view of investing in the stock market (buying when the tendency to increase or selling when it tends to decrease) perpetuate. To understand the characteristics of each one of the different types of investment you must have enough financial knowledge.

Furthermore, inflation has served to increased awareness of the importance of financial planning and wise investing. More Inflation is a worry for each and every individual. Due to Inflation value of your money in future will decrease. To Cope up this,
Investors wants to invest their money and earn certain rate of return which is more then rate of Inflation. Having clear reasons or purposes for investing is critical to investing successfully. Like training in a gym, investing can become difficult, tedious and even dangerous if you are not working toward a goal and monitoring your progress. In this Paper we examine some common reasons for investing.

The remainder of this paper is organized into seven sections. The Next (Second) begins with a brief review of previous research in this area. The third section provides a brief description of the research methodology employed in this study. Descriptive data analysis and the reliability and validity of the instrument are reported in the fourth section. The descriptive Analysis of generated factors is examined in the fifth section. Finally the Regression Analysis is reported in the Sixth Section. Finally in the seventh section, The paper Concludes with a discussion on the implications of these findings for management of Investing Companies and others to consider this in deciding the policies feature and other things.

\section{Literature Review}

Earlier studies have been carried out to determine the pattern of Institutional investors Investment but Studies dealing with Investment pattern of individual investors are very few. Previous Studies mainly concentrate on Differences in individual investing pattern on the basis of Gender. Differences on the basis of Age in Investment pattern is new avenue for research. Earlier studies conclude that women invest their asset portfolios more conservatively than their male counterparts. Women's investment has historically been lower than men's for several reasons, including Social and various demographic concerns. However the differences continue to be significant even after controlling for individual Characteristics (Schmidt \& Sevak, 2006).In making any Investment Decision Risk Aversion and Financial Literacy is a major factor. Although different literature available on risk define it variedly but in common the word risk refers to situations in which a decision is made whose consequences depend on the outcomes of future events having known probabilities(Lopes, 1987).

There is evidence that Women are more risk averse then men in general and this translates to investing in less risky assets in their investment plans(Julie R. 
Agnew,either,2003).Differences in financial literacy between men and women may also explain differences in their investment decisions. There is some research on individual investors for e.g. Langer (1975) finds that self reported risk tolerance does the best job of explaining differences in both portfolio diversification and portfolio turnover across individual investors.

Dunham (1984) admits that although personality factors can change over an extended period of time, the process is slow and tends to be stable from one situation to another. Therefore, these factors are expected to influence the decision making behavior of an individual. Barnewall (1987) finds that an individual investor can be found by lifestyle characteristics, risk aversion, control orientation and occupation. Barnewall (1988) suggests the use of psychographics as the basis of determining an individual's financial services needs and takes one closer to the truth from the customer's perspective of need to build a marketing program.

Statman (1988) observed that people trade for both cognitive and emotional reasons. They trade because they think they have information, when in reality they make nothing but noise and trade only because trading brings them joy and pride. Trading brings pride when decisions made are profitable, but it brings regrets when they are not. Investors try to avoid the pain of regret by avoiding realization of losses, employing investment advisors as scapegoats and avoiding stocks of companies with low reputations. Harlow and Brown (1990) observes that psychologists tend to believe that an individual's choice is primarily determined by factors unique to the particular decision setting, whereas economists assume that there is some individual $\neg$ specific mechanism playing a common role in all economic decisions.

Warren et al. (1990) and Rajarajan (2000) predict individual investment choices (e.g., stocks, bonds, real estate) based on lifestyle and demographic attributes. These investors see rewards as contingent upon their own behavior (Rajarajan, 2002). Gupta (1991) argues that designing a portfolio for a client is much more than merely picking up securities for investment. The portfolio manager needs to understand the psyche of his client while designing his portfolio. Risk tolerant investors behave as though they can control risk. This suggests that risk tolerance serves as a proxy for an 'illusion of control' and thus overconfidence [Madhusoodanan (1997); Odean (1998); Barber and Odean (2001);Benartzi and Thaler (2001); Gervais and Odean (2001); and Daniel and Huberman (2003)].

Barber and Odean (2000) explored the impact of intuitive thinking on investment preference to study the experience of actual investors. The ET Retail Equity Investor Survey (2004) in the secondary market identified different categories of investors based on their characteristics and attitude towards secondary market investments. A study by on 245 Kuala Lumpur Stock Exchange individual investors from Kula Lumpur and Petaling Jaya, reveal that there are some differences between active and passive investors in terms of demographic and psychographics, investment characteristics as well as investment behavior.

Karthikeyan (2001) has conducted research on Small Investors Perception on Post office Saving Schemes and found that there was significant difference among the four age groups, in the level of awareness for kisanvikaspatra (KVP), National Savings Scheme (NSS), and deposit Scheme for Retired Employees (DSRE), and the Overall Score Confirmed that the level of awareness among investors in the old age group was higher than in those of young age group. No differences were observed among male and female investors except for NSS and KVP.

National Council of Applied Economic Research (NCEA) (1961) 'Urban Saving survey' noticed that irrespective of occupation followed and educational level and age attained, households in each group thought saving for the future was desirable. It was found that desire to make provision for emergencies were a very important motive for saving for old age. Securities and Exchange Board of India (SEBI) and NCEAR (2000) 'Survey of Indian Investors' had been report that Safety and Liquidity were the primary considerations which determined the choice of an asset. In this paper we are trying to find out the Factors which influence individual investment decision, the difference in the perception of Investors in the investing process on the basis of Age and the difference in perception of the Investors on the basis of Gender.

The present study aims to put on some knowledge about key factors that influence investment behavior and ways these factors impact investment risk 
tolerance and decision making process among men and women and among different age groups. The individuals may be equal in all aspects, but their behavior is different in same situation. Earlier studies did research but they did this only gender wise, in this study we are trying to find out the factors which affects individual investment decisions by considering both age and gender wise. Hence keeping this in mind, the present study is an attempt to find out Factors which affects individual investment decision and Differences in the perception of Investors in the decision of investing on basis of Age and on the basis of Gender.

January effect - An anomaly in the financial market where the price of a security increases in the month of January without fundamental reasons. (Rozeff\&Kinney, 1976)

The winners curve- Where the winning big in an auction tends to exceeds intrinsic value of the item purchased, mainly due to incomplete information\& emotions leading bidders to over estimating the items value.(Thaler1988)

As more and more anomalies were recorded, then scholars began wondering whether the traditional finance theories were incapable of explaining what determine the stock prices. Stock market performance is not simply the result of intelligible characteristics, but the investors' fear\& greed, risk aversion etc. which seems to decisively device \& dictate the fortune of the market.

\section{Objectives of the Study:}

1. To identify investment behavior of the different age groups.

2. To provide an up-to-date $\&$ comprehensive review of studies on individual investors' behavior in the financial markets how the generation gap is doing the role in share markets.

3. Factors which affects individual investment decision.
4. Difference in perception of Investors in the decision of investing on the basis of Age.

5. Difference in perception of Investors in the decision of investing on the basis of Gender.

\section{Methodology}

The study is based on secondary data sources. For the present study, a thorough review of existing empirical literature has been collected from various online databases\& search engines such as SSRN\& Google scholar were reviewed and various books on Investor behavior were reviewed from various existing literature, Academicians\& researchers have identified various factors influencing the behavior of an individual investors.

These factors are

\section{Behavioral Factors:}

\section{a) Heuristic factors:}

These factors explain the way investor thinks\& how they organize the information.

\section{b) Emotional factors:}

These factors explain the way investor feels about the information.

\section{c) Herd behavior:}

Herding is the tendency of investors' behavior to follow the others' actions.

\section{Contextual Factors:}

These factors are suggested by the professionals\& contextual sources which include stock brokers, financial consultants\& investment advisors.

Along with these, there are certain market factors\& demographic factors such as age, gender, income, education\& experience etc. were explored from the existing literature. 


\section{Table shows the Factors affecting the investment behavior of Individual investors:}

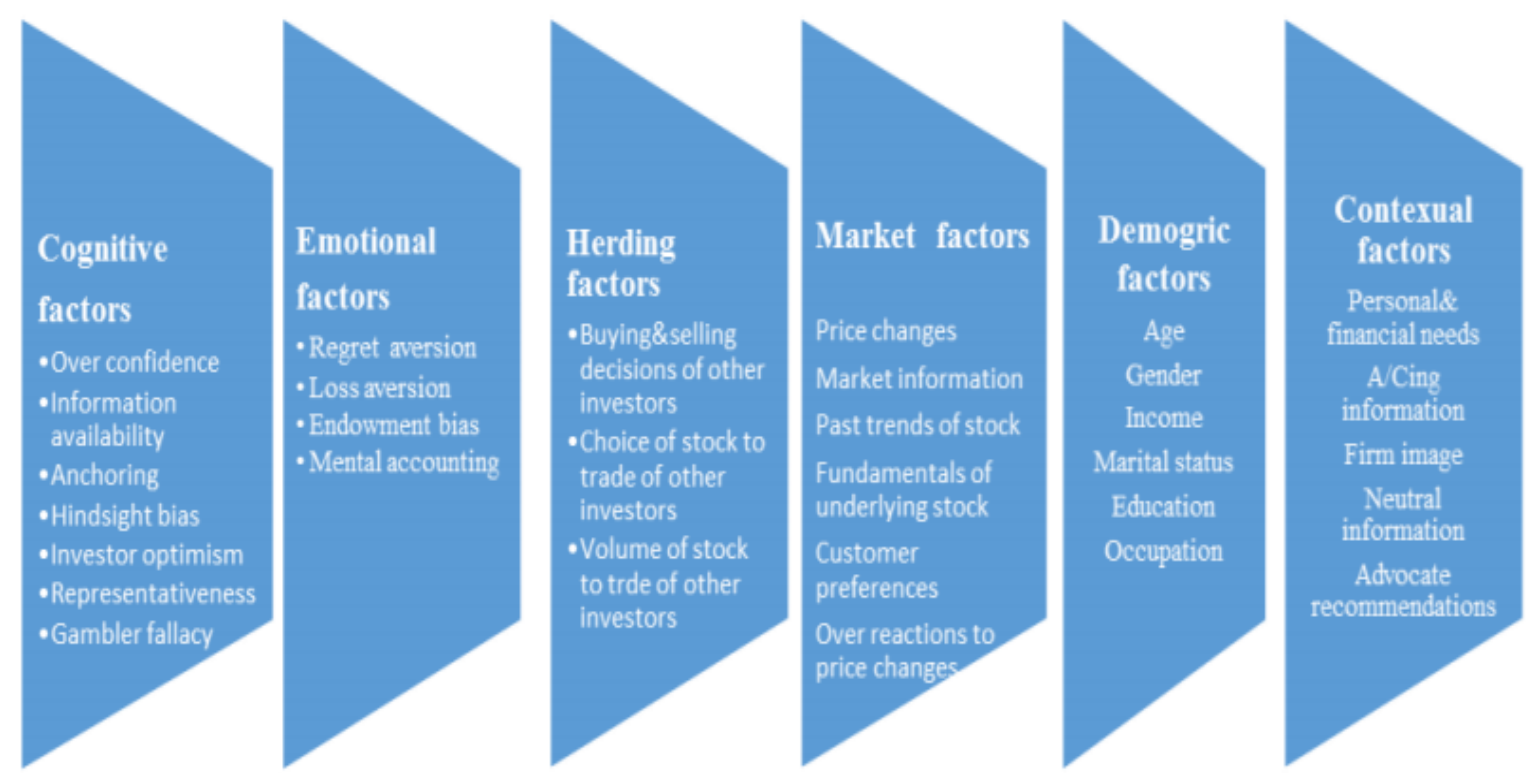

\section{Analysis:}

From the review of above studies, it can be understood that individual investors do not act rationally while making investment decisions. There are various factors identified from the existing literature which have an influence on their investment decisions. These factors are Behavioural factors such as Cognitive factors\& Emotional factors, Herd behaviour, Contextual factors, Market factors\& Demographic factors. Warren(1990) , ShahlaAmiri, NooredinRazavizade, GholamHoseinVahidi (2011),Kabra, Prashant kumar, Manoj kumar dash(2011) have explored various demographic factors such as age, gender, income, education \& experience influence the individual investor behaviour.

Nagy\&Obenberger(1994), Tomola Marshal Obamuyi (Nigeria), Dr. Syed Tabassum, Dr S Pardhasaradhi(2012) have identified 34 Contextual factors grouped in to 5 categories such as personal\& Financial needs, A/C ing information, Neutral information, Firm image\& Advocate recommendations have an influence on individual investor behaviour. Dimitrios I. Maditinos, ŽeljkoŠevic, Nikolaos G. Theriou (2007) had conclude that Individual investors rely more on newspapers/media and noise in the market when making their investment decisions, while professional investors rely more on fundamental and technical analysis and less on portfolio analysis.

Geoffrey GitauMwangi, (2011) was found that heuristic factors such as anchoring, representativeness $\&$ availability bias has more influence on property investment decisions. Le Phuoc Luong Doan Thi Thu Ha 2011 had conclude that there are five behavioural factors affecting the investment decisions of individual investors such as Herding, Market, Prospect, Overconfidence-gamble's fallacy, and Anchoring-ability bias. Abhijeet Chandra and Ravinder Kumar (2011) from their research found that there some psychological axes, such as conservatism, under confidence, prudence, precautious attitude and informational asymmetry which have an influence on investor decision making. Sohani Islam (2012) had found that Psychological factor is the most dominating influence upon investor's decision making process \& micro economic factor and social factor also have influence on selecting investment securities. 


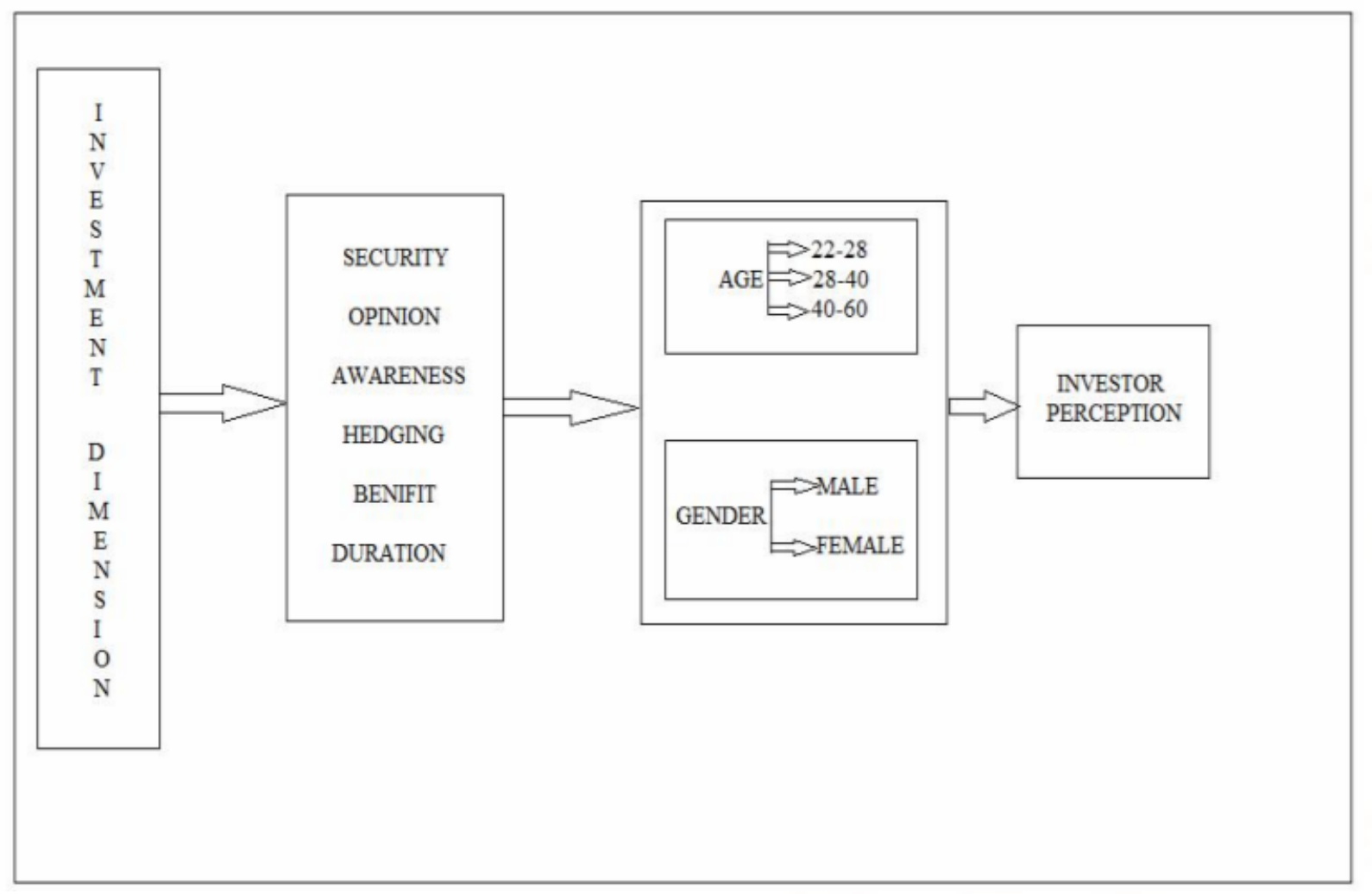

The above table highly explained about the importance given to the age of the investors for how the investment gets vary among various age groups.

\section{DISCUSSION \& CONCLUSION}

It can be concluded that the modern investor is a mature and adequately groomed person. In spite of the phenomenal growth in the security market and quality Initial Public Offerings (IPOs) in the market, the individual investors prefer investments according to their risk preference. For e.g. Risk averse peoples chooses life insurance policies, fixed deposits with banks and post office, PPF and NSC. Occasions of blind investments are scarce, as a majority of investors are found to be using some source and reference groups for taking decisions. Though they are in the trap of some kind of cognitive illusions such as overconfidence and narrow framing, they consider multiple factors and seek diversified information before executing some kind of investment transaction. The purpose of this study was to determine whether the variables such as demographic characteristics (age, gender) and investment patterns to the investment managers to design their investment schemes by considering these views of individuals.

\section{REFERENCES}

1) "The ET Retail Equity Investor Survey" (2004), The Economic Times, January 16. pp 5

2) Barber B and Odean T (2001), "Boys will be Boys: Gender, Overconfidence and Common Stock Investment", Quarterly Journal of Economics, Vol. 116, No. 2, pp 261292.

3) Barber B M and Odean T (2000), "Trading is Hazardous to Your Wealth: The Common Stock Investment Performance of Individual Investors", Journal of Finance, Vol. 55, No. 2, pp 5667.

4) Barber, B.and Odean, T. (2001). "Boys Will Be Boys; Gender, Overconfidene and common stock investment",Quarterly Journal of Economics 116, pp. 261292

5) Barnewall M (1987), "Psychological Characteristics of the Individual Investor", in WilliamDroms, ed., Asset Allocation for the Individual Investor,

Charlottsville, Va:

The Institute of

Chartered Financial Analysts.

6) BarnewallMacGruder M (1988), "Examining the Psychological Traits of Passive and Active Investors", Journal of Financial Planning, available at www.fpanet.org/journals/ articles/19 88_issues 
7) BenartziShlomo and Richard H Thaler (2001), "Naïve Diversification in Defined Contribution Saving Plans", American Economic Review, Vol. 91, No.1, pp 2345.

8) Daniel Dorn and Huberman Gur (2003), "Talk and Action: What Individual Investors ASIAN JOURNAL OF MANAGEMENT RESEARCH 325 Say and What They Do", European Finance Association Meetings in Glasgow, December 16.

9) Dash

Manoj

Kumar(2010),"Comparative Empirical Analysis of Occupational and Motivational Differences of Different Generation in Indian Work Force ", International Journal of Business Research, IABE Journal, pp 1723.

10) Dunham Randall B (1984), Organizational Behavior, Homewood, Illinois

11) Gervais S and Odean T (2001), "Learning to be Overconfident", Review of Financial Studies, Vol. 14, No. 1, pp 127.

12) Gupta Ramesh (1991), "Portfolio Management: The Process and Its Dynamics", Working Paper No. 923, JanuaryMarch, Indian Institute of Management, Ahmedabad.

13) Harlow W V and Keith C Brown (1990), The Role of Risk Tolerance in The Asset Allocation Process: A New Perspective, Association for Investment Management.

14) Langer E J (1975), "The Illusion of Control", Journal of Personality and Social Psychology, Vol. 32, No. 2, pp 311328.

15) Lobes (1987)." An Analysis of Investor's Risk Perception towards Mutual Funds Services", Intenational journal of business and management. Vol 4, pp 234236.

16) Madhusoodanan $\quad T \quad P \quad$ (1997), "Risk and Return: A New Look at the Indian Stock Market", Finance India, Vol. 11, No. 2, pp 285304.

17) Odean T (1998), "Volume, Volatility, Price and Profit When All Traders are Above Average", Journal of Finance, Vol. 53, No. 5, pp 17751798.

18) Rajarajan V (2000), “Investor's Lifestyles and Investment Characteristics", Finance India, Vol. XIV, No. 2, pp 465478.
19) Rajarajan, V.,"investor's Life styles and Investments Characteristics ", Finance India,June, Vol.XIV No.2(2000), pp 465478

20) Schmidt,Lucie \&Sevak,P.(2006)."Gender,Marria ge, andAssest Accumulation in the United States".Feminist Economics, 12(12), pp 139166. 21. Statman Meir (1988), "Investor Psychology and Market Inefficiencies", in Katrina F Sherrerd (Ed.), Equity Markets and Valuation Methods, The Institute of Chartered Financial Analysts, Charlottesville, Virginia 